\title{
Evaluation and Simulation of a Large Scale Pilot Water Farm Project in South Florida
}

\author{
Christopher J. Brown \\ University of North Florida, Jacksonville, Florida.
}

\begin{abstract}
South Florida, U.S.A. is in the midst of enormous change driven by steady population growth. At the same time the citrus industry has been struggling to contain outbreaks of citrus greening which threaten an important industry in the region. To add to this complexity, the re-plumbing of the Everglades ecosystem, which aims to redirect the flow of surface and groundwater to more natural patterns, is underway. Currently, flow out of Lake Okeechobee is shunted mostly eastward or westward through massive flood control canals. On the east side of Lake Okeechobee water is directed down the C-44 (St. Lucie) canal towards the Atlantic Ocean. These large pulse releases of freshwater can wreak havoc in the St. Lucie Estuary as flora and fauna can be shocked by the near-instantaneous change in salinity due to the large releases as well as by the impacts of nutrients carried in the flows.

This study focuses upon a pilot water farm project implemented to provide some interim water storage and treatment benefits in the watershed. This study summarizes the results of a comprehensive assessment of the water farm performance, concentrating on the fate of stored water as well as the overall cost effectiveness of the project. The assessment was greatly aided by the development of complementary simulation tools using MODFLOW and Solver, which is also discussed. Finally, this paper discusses how this idea can be scaled up and used in other projects to support the restoration of the Everglades and overall sustainable development in Florida and other places further afield.
\end{abstract}

\section{Methodology}

\subsection{Overview}

This paper summarizes the overall technical assessment of a 168 ha water farm, an artificial recharge pilot project located in Martin County, Florida that is designed to collect water from the nearby C-44 canal and percolate the water into the surficial aquifer system. The water farm project has been in operation since February 2014. This pilot project is one component of the South Florida Water Management District's (SFWMD) dispersed water management program which is designed to partner with private landowners around Lake Okeechobee to either store or retain excess stormwater on their properties (SFWMD 2013).

The water farm project is located in central Martin County between the Atlantic Ocean to the east and Lake Okeechobee to the west. Figure 1 shows the general location of the project in Florida. The topography in the study area is a reflection of the geologic history of Florida which has been subjected to periodic inundation by the Atlantic Ocean (Schmidt 1997). The water farm is located in the Eastern Valley physiographic region of Florida and is located between the Osceola Plain high ground and the Green Ridge region (Schmidt 1997). Overall the study area is relatively flat with surface elevations ranging from $9.5 \mathrm{~m}$ (NGVD 1929 vertical datum) east and west of the site to $7 \mathrm{~m}$ south of the site along the C-44 canal. According to high resolution topographic data from the United States Geological Survey (Desmond 2007), the median ground elevation of the water farm is $7.65 \mathrm{~m}$.

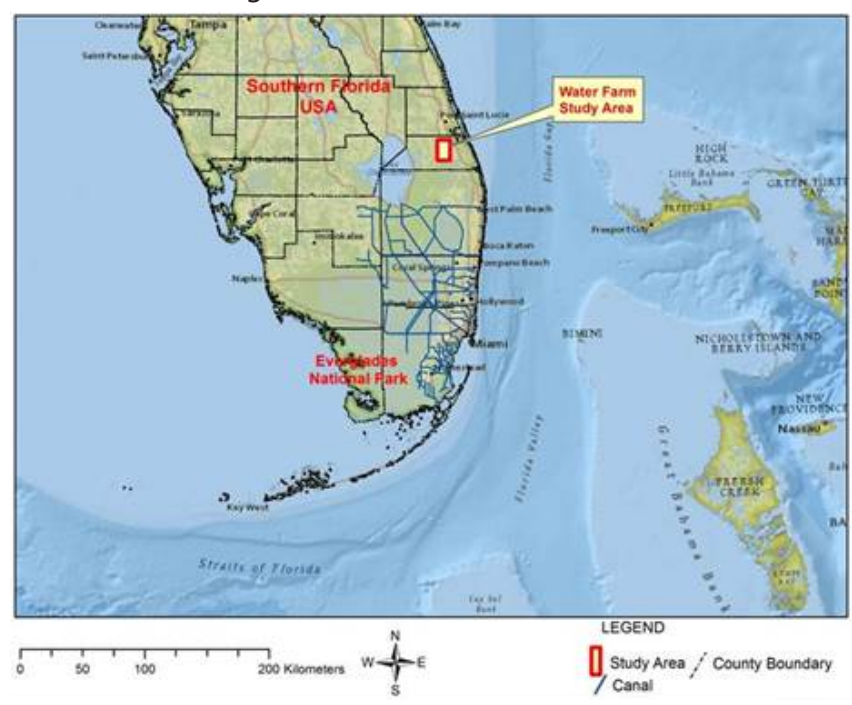

Figure 1 Project study area in South Florida.

Brown, Christopher J. 2018. "Evaluation and Simulation of a Large Scale Pilot Water Farm Project in South Florida." Journal of Water Management Modeling 26: C452. doi: 10.14796/JWMM.C452.

(c) CHI 2018. www.chijournal.org ISSN 2292-6062. 
Design of the water farm levees, pump station, and overflow structures was performed by the MilCor Group Inc. in August and September 2013 (MilCor Group 2013). According to the MilCor plan sheet the exterior levee surrounding the water farm project is approximately $2 \mathrm{~m}$ ( $\sim$ feet) high with $1 \mathrm{~V}: 3 \mathrm{H}$ interior side slopes and 1V:2.5H exterior side slopes. According to MilCor Group computer aided drafting and design (CADD) files, the area of the water farm varies from about 166 ha at the interior levee toe of slope to 169 ha at the interior levee top of slope (MilCor Group 2013). Two emergency overflow weir structures with trash racks are located on the west side of the water farm.

The water farm project withdraws water from the C-44 canal using an onsite irrigation pump station. One objective of the pilot project is to store excess stormwater from the C-44 canal instead of discharging the water into the St. Lucie Estuary where it may cause harm to the local ecology as well as reduce the ability of local citizens to take advantage of the abundant recreational activities related to the estuary. These flows occur in an episodic fashion and can be of great magnitude and cause extensive ecological damage (USACE and SFWMD 1999). It is hoped that projects like the water farm will reduce these damaging pulse releases to the St. Lucie Estuary through more efficient storage and retention of the excess stormwater.

This paper will concentrate on an overall assessment of the pilot project regarding two items:

- development of an overall site water budget based upon observed data and model simulations; and

- assessment of the overall cost effectiveness of the site as compared to proposed Everglades restoration projects planned in the vicinity.

\subsection{Overview of Artificial Recharge Projects}

The concept of underground water storage has existed for millennia, with nomads in the Middle East using sand dunes as a dependable source of recharge storage after rain events (Brown 2005). The modern term artificial recharge has been recognized only recently through the efforts of notable engineers and scientists such as Cederstrom (1947) and Harpaz and Bear (1964).

Recharge to groundwater aquifers is ultimately derived from rain that falls on the land. Much of the rainfall runs off to nearby surface water bodies, evaporates, or is abstracted (e.g. pumped) for various water supply uses. Only a fraction of the total rainfall reaches subsurface aquifers via percolation into the ground (ASCE 2001; Brown 2005).

Modern artificial recharge (AR) is the process of augmenting natural recharge of groundwater aquifers (NRC 1994). Both unconfined and confined aquifers have been used for AR (ASCE 2001). Surface spreading methods are mainly amenable in unconfined aquifers (Asano 1985), while wells are utilized to recharge confined aquifers (NRC 1994). Surface spreading methods introduce water on the land surface into unconfined aquifers. The water farm project was conceived around this idea. The percolated water passes through permeable geologic material and enters into the water table or surficial aquifer. Technical factors affecting the feasibility of such an approach include infiltration rates, depth to water table, recharge water quality, and the degree of hydrologic continuity between the surface and the water table (Wilson 1979; Bouwer et al. 1990; NRC 1994). Surface spreading can be accomplished through recharge basins, in-channel recharge zones, off-channel recharge zones, leach mounds and other techniques. According to Abe (1986), advantages of surface spreading include:

- construction costs are generally much lower for spreading facilities than for recharge wells;

- operation and maintenance costs are generally lower and little to no water treatment is required prior to recharge;

- large volumes of water may be recharged rapidly;

- channel modification takes advantage of natural hydrologic connections with unconfined aquifers; and,

- recharge near streams may provide for environmental enhancement.

Also according to Abe (1986), disadvantages of surface spreading include:

- evaporation losses may be higher than for recharge wells;

- time lag between recharge and recovery (as baseflow or from pumping) may be substantial;

- land availability or costs may be substantial;

- floods or animals (e.g. turtles, rodents) may periodically cause severe damage to containment dikes;

- surface recharge basins can become attractive nuisances (e.g. attracting mosquitoes or potential for drowning); and,

- periodic scraping may be required in the surface recharge basins to restore full infiltration capacity.

AR projects have been constructed throughout the world and have been studied extensively for their hydrologic effectiveness (Vecchioli 1976; Bouwer 1978; Wilson 1979; Driscoll 1986; Bouwer et al. 1990; Rabbani and Munch 2000; Bouwer et al. 2008; Brown et al. 2014). Both Brown et al. (2014) and Rabbani and Munch (2000) discuss successful projects within Florida. AR projects, also dubbed soil aquifer treatment (SAT) projects when evaluating water quality benefits, have also been evaluated for their nutrient (total nitrogen, TN, and total phosphorus, TP) removal benefits since the early 1980 s. Bouwer et al. (1980) completed the initial field-scale and lab-scale evaluations of the water treatment capabilities of AR projects. Many other studies have been completed since that time evaluating the nutrient removal efficiency of AR projects (Suzuki et al. 1992; Nema et al. 2001; Van Cuyk et al. 2001; Idelovitch et al. 2003; Tucker and Diblin 2007; Nagarasappa et al. 2010; Schmidt et al. 2011; Hamadeh 2014). Most of these studies used treated wastewater water as influent into the AR or SAT system. Although the water quality performance of the pilot site is not the focus of this paper, UNF did assume (based upon the literature) that the site was capable of achieving $50 \%$ removal of TN and $75 \%$ removal of TP. 


\subsection{General Geology and Hydrogeology}

Florida is a child of the sea and its landforms show the dominant effect of marine forces in shaping the land surface (Schmidt 1997). Over the last 5 million years ocean levels have risen and fallen, causing alternating periods of inundation of the Florida peninsula. Marine forces have left a strong imprint on today's Florida including the area around the water farm. In the study area, the existing ridges and Osceola Plain are a result of marine transformation. Over geological time, a substantially thick amount of sediment has been deposited on top of ancient Florida basement rock. In some areas this sequence of sediments is $>1 \mathrm{~km}$ thick.

The water farm is located in Martin County and sits atop a complicated layer cake geology. Generally, the site is underlain by sand, clay and carbonate rocks. The hydrogeology of Florida is dominated by three important aquifer systems: the surficial aquifer system (SAS), the intermediate aquifer system (IAS), and the Floridan aquifer system (FAS) (State of Florida 1986). The FAS is probably the most heavily used of the three aquifer systems since it underlies all of Florida (Miller 1997). The IAS is located stratigraphically in the middle of the Hawthorn Group that separates the FAS from the shallower SAS. The SAS is the aquifer system of interest for this study. The SAS ranges from $<15.24 \mathrm{~m}$ thick to as much as $122 \mathrm{~m}$ thick in St. Lucie County (Miller 1997). Within the study area, the SAS ranges from $\sim 42.67 \mathrm{~m}$ to $50.29 \mathrm{~m}$ thick and generally thickens to the east.

The SAS includes beds of unconsolidated sand, shelly sand, shell, and occasional limestone. Limestone beds are locally important high yielding parts of the aquifer system, particularly in areas north and west of the Fort Lauderdale area (Miller 1997). The SAS also includes local clay beds that can create localized confined aquifer conditions. However, for the most part the SAS is an unconfined or water table aquifer. Most water that enters the SAS as recharge moves along short flow paths and discharges as base flow to local streams (Miller 1997) as is the case in the study area where most recharge that is derived from precipitation or irrigation flows as discharge back to the C-44 canal. A detailed study of the Upper East Coast Planning Area completed by SFWMD in 1996 included aquifer tests and well drilling in the water farm study area (Lukasiewicz and Smith 1996).

The SAS in the water farm study area includes a number of geologic units including the Pamlico sand, Anastasia formation, Fort Thompson formation, and portions of the Tamiami formation (Lukasiewicz and Smith 1996). The SAS is separated into three primary hydrogeologic units including:

- unconsolidated sand;

- sandy shell bed and sandstone beds; and

- granular limestone unit.

According to the SFWMD study, the sandy shell beds and sandstone beds are the primary water supply production unit in the study area and, as such, are the most permeable portion of the SAS. However, water level data collected by USGS in support of the 1996 study found that, with a few exceptions, water levels in each of the three hydrogeologic units were very similar, indicating a well-connected aquifer system. Similarly, a three-dimensional MODFLOW model of the study area showed that water levels in the three zones were practically the same in the water farm study area with head differences generally $<1 \mathrm{ft}(0.30 \mathrm{~m})$ (Lukasiewicz and Smith 1996).

Soil testing and aquifer tests conducted in the study area (SFWMD 1984; Lukasiewicz and Smith 1996; and CDM 2004) revealed a range of hydraulic conductivity for the aquifer system ranging from as low as $0.031 \mathrm{~m} / \mathrm{d}$ for clayey sand materials to as high as $71 \mathrm{~m} / \mathrm{d}$ for coarse sand or limestone zones. Figure 2 provides a generalized geologic cross section of the study area along with primary components of the pilot water farm water budget.

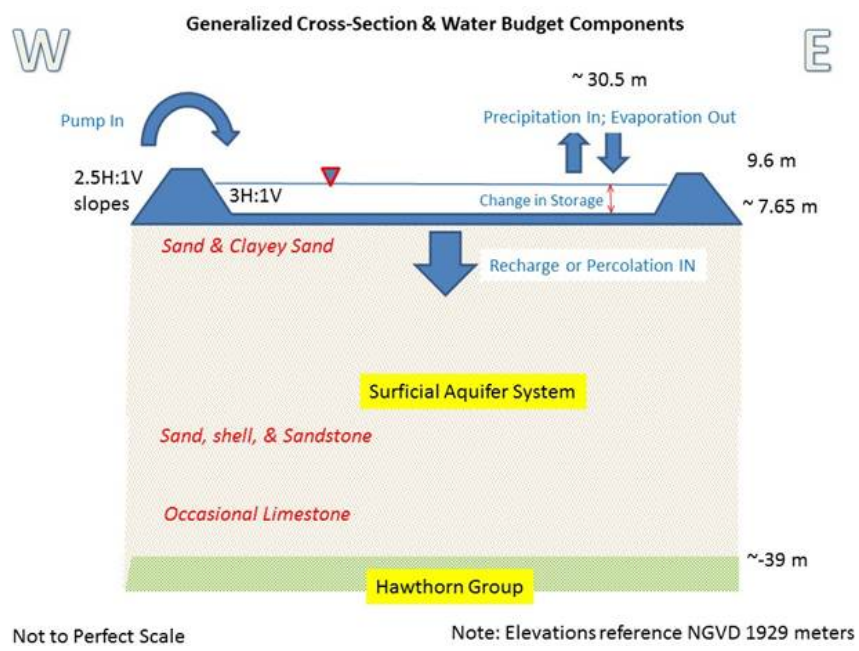

Figure 2 Project study area showing generalized geologic cross-section.

\subsection{Assessment Procedure}

The overall pilot site assessment methodology included four primary steps including:

- regional data compilation;

- analysis of site-specific field data;

- model development; and

- data synthesis (discussed in the Results section of this paper).

Regional data collection focused upon important datasets ranging from topographic surveys to regional groundwater or surface flow information. Water quality data for the C-44 canal was also collected and synthesized but that data is not discussed herein. Similarly, site specific water quality nutrient data was also collected and analysed but it is not discussed in this paper. The reader is referred to the UNF final project report for the evaluation of pilot site water quality data (Brown and students 2015). Besides the regional and site specific field data, the assessment of the pilot site relied heavily upon the development of several numerical models including a water budget optimization model, a HEC-HMS model (USACE 2000), and a groundwater MODFLOW model (McDonald and Harbaugh 1988). In this paper the water budget optimization model is discussed in detail while the 
MODFLOW model is briefly discussed insofar as it corroborates the water budget study. The HEC-HMS model is not discussed. All three model development and calibration efforts are thoroughly outlined in the final UNF report.

\subsection{Regional Data Compilation}

In addition to the geologic and hydrogeologic data used in this study and discussed above, many other datasets were reviewed, compiled, analyzed, and summarized as part of the overall assessment of the water farm including:

- regional topographic data;

- regional evaporation and evapotranspiration data;

- regional runoff and recharge data;

- aerial photography and regional maps;

- regional groundwater data;

- regional water quality data for the C-44 canal watershed;

- daily water level data for the C-44 canal; and

- daily flow data for the C-44 canal.

Some of these datasets were used in model development efforts discussed later in this paper. A few of the critical datasets are discussed herein. Figure 3 shows the water farm as well as other important features in the project area including the locations of key instruments used in the study.

Regional evaporation (EV) and evapotranspiration (ET) data were important for the study since these phenomena result in water leaving the study area so they are critical to the overall water farm water budget. UNF compiled many sources of EV and ET data for this study including:

- pan evaporation coefficients for Martin County (Miller 1978);

- regional data from the Upper St. Johns River basin (Mao et al. 2002);

- site specific data from Martin County-Vero Beach, Florida (State Climate Office of North Carolina 2014);

- regional data from SFWMD technical study (Abtew et al. 2010); and

- site specific data from SFWMD real-time weather station ACRA or Allapattah Tract weather station (downloaded from DBHYDRO database).

Although the monthly values presented in the literature varied somewhat, they were generally consistent with the highest values recorded during the wet season (i.e. May-September) with its typical higher temperatures, longer days, higher winds and more intensive vegetation development. After a review of the ET data, the ACRA/Allapattah Tract weather station was utilized for the project assessment and model development as the data was available in real time and the data collection site was located adjacent to the pilot project. Table 1 shows the monthly ET data from ACRA.
Table 1 Monthly ET data in $\mathrm{cm} / \mathrm{month}$.

\begin{tabular}{cc}
\hline Month & ET Data (ACRA) \\
\hline January & 8.15 \\
February & 9.45 \\
March & 12.78 \\
April & 14.25 \\
May & 15.34 \\
June & 14.3 \\
July & 12.85 \\
August & 14.38 \\
September & 11.23 \\
October & 11.99 \\
November & 8.53 \\
December & 8.33 \\
\hline
\end{tabular}

\subsection{Analysis of Site Specific Field Data}

As seen in Figure 3, a significant ridge and likely drainage divide is located along the northeastern side of the Caulkins property line. This ridge is thought to also be a groundwater flow divide. Another important feature shown in Figure 3 is the large drainage canal located west of the water farm. This canal will ultimately be used as a major seepage collection canal for the proposed USACE and SFWMD C-44 (IRL) reservoir/STA complex. This large canal is a significant groundwater sink in the study area. In addition to this new drainage canal, the C-44 canal is itself a major groundwater sink in the study area and likely collects most of the baseflow from the SAS. Thus it appears that the water farm is surrounded by major watershed sinks or topographic divides. The only area where a clear watershed boundary does not exist around the Caulkins property line is the northwestern portion of the property. Groundwater levels in this area are likely driven by a combination of recharge, evapotranspiration and local irrigation canal pumping. Luckily, there is some limited regional groundwater data to estimate water levels in this area which is discussed in later sections of this study. Base map Source: ESR Background Groundwater Levels 11/17/2014 (NGVD 1929, feet)

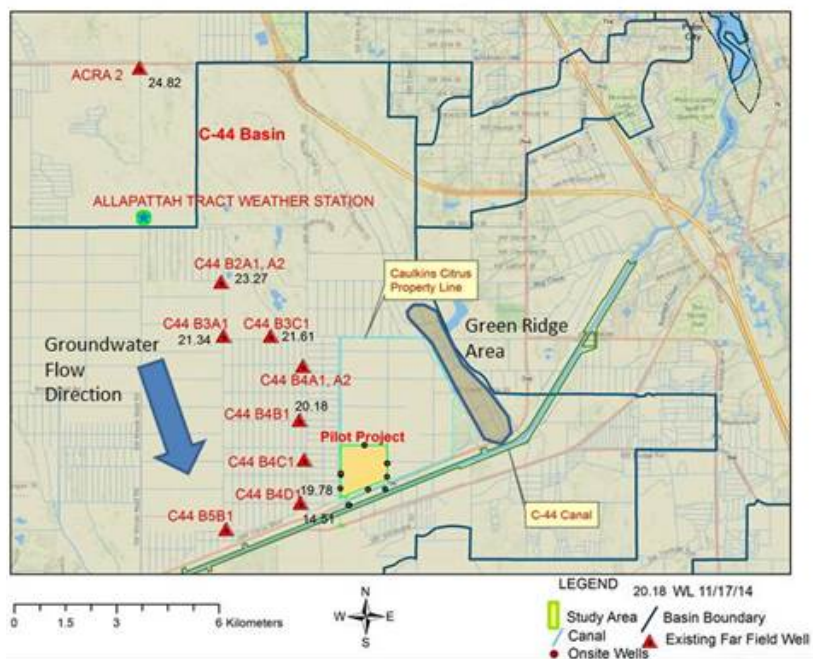

Figure 3 Detailed project study area and regional instruments locations. 
Figure 4 shows a detailed site map of the water farm pilot project including the location of important instruments. Figure 4 depicts the location of both groundwater observation wells (e.g. MW-5S, 5M, 5D) and surface water staff gauges (e.g. SG-1) installed around the project site and in the entrance canal from C-44. The various instruments were installed with different screen intervals to monitor discrete aquifer zones beneath the pilot site. Shallow wells are designated with an S, mid-depth wells are designated $\mathrm{M}$ and deep wells are designated $\mathrm{D}$. Data collection from these instruments began in October 2014 and continues today (2018). For this study, data collected from October to December 2014 was used for evaluation purposes.

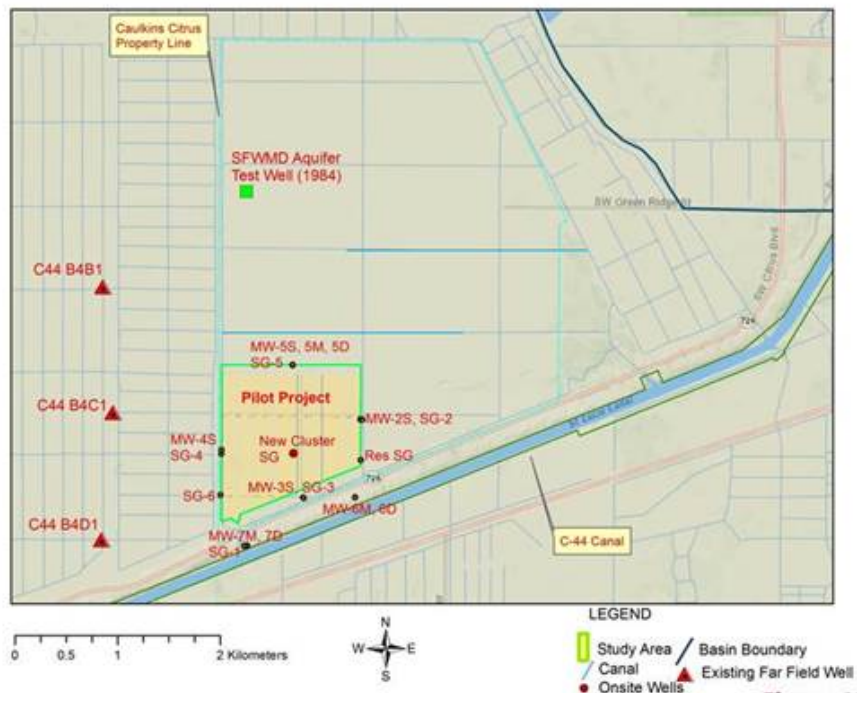

Figure 4 Pilot project location with local wells and gauges.

\subsection{Model Development Procedure}

To aid with the analysis and interpretation of field data from the water farm as well as to assess possible project scale-up issues, UNF developed three different computer models; two of those are discussed herein. The primary model was a water budget model developed in Microsoft Excel. Limited results of the MODFLOW (McDonald and Harbaugh 1988) model are presented to provide further confirmation of the Excel estimates. The Excel water budget model was designed to incorporate all water inputs and outputs from the water farm in order to estimate the weekly infiltration-recharge or percolation rate. The water inputs and outputs at the water farm can be summarized as follows:

daily inflow pumping; daily inflow from precipitation; daily outflow from ET; and daily outflow from recharge.

Once total inflows exceed outflows, the water level in the water farm rises and storage builds up in the water farm. Equations (1) and (2) summarize the conservation of mass for the system.

$$
\begin{aligned}
& \text { (Pump INFLOW }+ \text { Precipitation INFLOW }) \\
& \quad-(\text { ET OUTFLOW }+ \text { Recharge OUTFLOW }) \\
& =\text { Change Storage } \pm \text { Error }
\end{aligned}
$$

Equation (2) can be rearranged such that Recharge OUTFLOW is the only unknown in the Excel model with the assumption that Error will be included as part of this recharge outflow estimate. Therefore, with all inflows known, ET known, and storage known, the water budget model calculates the mean daily percolation or recharge rate on a weekly basis from 2014-02-01 to 2015-04-15. The model estimates a value for the stage in the water farm each day and compares the estimate to the actual recorded stage via guesses in recharge outflow. Then the difference between the two values is calculated and residual difference is minimized by revising the recharge guess using an automated nonlinear optimization package contained in Solver (Frontline Systems 2010), which is an add-in program to Excel. The overall water budget model is also constrained to ensure that the conservation of mass is accurate. This is accomplished by summing all inflows and outflows in the model and then calculating the change in storage as of 2015-04-15.

The water farm has a simple operational scheme. Water from the C-44 canal is pumped into an irrigation canal running parallel to the C-44 canal but located just north of NW Citrus Blvd using an existing irrigation pump station operated by Caulkins Citrus Company. A new pump station was constructed as part of the water farm pilot project. This pump station, located just to the east of the irrigation station, lifts water from the irrigation canal into the water farm. The remaining inflow irrigation canal water is provided to Caulkins leaseholders located on the northern portions of the Caulkins property.

The new pump station flow rate was calibrated previously in 2014 such that continuous inflow measurement is provided on a daily basis. The pump station is also equipped with water quality collection devices courtesy of the SFWMD. In addition to the daily water farm inflow, an onsite rain gauge provides $7.5 \mathrm{~min}$ precipitation estimates using a tipping bucket rain gauge. UNF processed the $7.5 \mathrm{~min}$ precipitation data into daily precipitation estimates across the entire portion of the water farm enclosed in levees. Precipitation that falls in the water farm is assumed to be contained as runoff storage due to the presence of the levees. ET data is calculated in real time at the ACRA weather station located north of the water farm. This data was used directly in the water budget model. The overall change in water storage of the water farm is easily calculated from observed stage data recorded inside the water farm combined with the water farm surface area, which ranges from 166 ha to 169 ha depending upon the water depth in the farm at any given time (see Figure 3 above for the location of the reservoir surface gauge, Res SG).

This comparison was completed using three different statistical measures: the correlation coefficient, the coefficient of determination and the Nash-Sutcliffe efficiency coefficient 
(NSE). The coefficient of correlation ( $r$ ) measures the strength and direction of the linear relationship between variables of the measured gauge data and simulation data. The calculated $r$ value will be between -1 and 1 , with 0 representing no correlation. The coefficient of determination $\left(r^{2}\right)$ gives the variance of the data and assesses a goodness of fit at each calibration point for the model. The equation for $r^{2}$ is given as Equation 3. The coefficient of determination is between 0 and 1 , with 1 indicating a perfect fit with all variation explained. As the coefficient approaches 1 , the overall ability of the model to more accurately produce better predictive simulations increases.

$$
r^{2}=\left(\frac{\sum_{i=1}^{n}\left(O_{i}-\bar{O}\right)\left(S_{i}-\bar{S}\right)}{\sqrt{\sum_{i=1}^{n}\left(O_{i}-\bar{O}\right)^{2}} \sqrt{\sum_{i=1}^{n}\left(S_{i}-\bar{S}\right)^{2}}}\right)^{2}
$$

where:

$$
\begin{aligned}
O_{i} & =\text { observed discharge data on the ith day, } \\
S_{i} & =\text { simulated discharge data on the } i \text { th day, } \\
\bar{O} & =\text { observed mean value, } \\
\bar{S} & =\text { simulated mean value, and } \\
n & =\text { number of observations. }
\end{aligned}
$$

NSE (Nash and Sutcliffe 1970) is a normalized statistic that determines the relative magnitude of the residual variance compared to the measured data variance and indicates how well the plot of the observed data versus the simulated data fits the 1:1 line (Wang et al. 2009). The NSE equation is shown in Equation 4.

$$
N S E=1-\frac{\sum_{i=1}^{n}\left(O_{i}-S_{i}\right)^{2}}{\sum_{i=1}^{n}\left(O_{i}-\bar{O}\right)^{2}}
$$

where:

$$
\text { NSE = Nash-Sutcliffe efficiency coefficient. }
$$

\section{Results and Discussion}

\subsection{Regional Field Data}

An important consideration in the overall water farm assessment was the effect of the water farm on the regional groundwater table. Regional groundwater data were available from historic maps developed by Hoy (1964), from observation wells installed by the USACE west of the water farm site as part of the C-44 reservoir complex planned for the future as part of the Everglades restoration (USACE and SFWMD 1999), and from SFWMD at the Allapatah natural area. The Hoy map depicts a probable area of SAS recharge to the northwest of the water farm project. Lukasiewicz and Smith (1996) show similar water levels from their calibrated MODFLOW model of the study area. Their Figure 15 depicts water levels in the shallow SAS and confirms an area of higher groundwater elevations (>7.5 m) northwest of the water farm area. More recent SAS data collected by the USACE and SFWMD from regional onsite observation wells shows that groundwater in the SAS flows generally towards the C-44 canal from recharge areas in the northern portions of the watershed (Dr. June Mirecki, personal communication, February 2015).

SAS water levels range from $7.56 \mathrm{~m}$ (24.82 feet) at the ACRA 2 canal to $6.03 \mathrm{~m}$ (19.78 feet) at the C44 B4D1 well near the C-44 canal. These and other water level data reviewed for the study indicate a groundwater gradient between regional observation wells C44 B2A2 and B4D1 to be to be $1.54 \times 10^{-4}$. Assuming the maximum SAS horizontal hydraulic conductivity value and an aquifer porosity of $35 \%$, the maximum background groundwater velocity is estimated to be $0.032 \mathrm{~m} / \mathrm{d}$. That means a particle of water recharged near well C44 B2A2 would take $>600$ y to travel to well C44 B4D1. On the other hand, travel time from well C44 B4D1 to the C-44 canal (on 2014-11-17) is much faster due to a steeper discharge gradient of $2.54 \times 10^{-3}$. The maximum groundwater velocity in this area near the C-44 canal is $\sim 17$ times faster than in upgradient areas. Maximum travel times from C44 B4D1 to the C-44 canal are estimated to be $\sim 3 \mathrm{y}$. The location of the water farm means that water pumped into the water farm may discharge to the C-44 canal at an even faster rate due to the steepening of the gradient from site operations. A review of the regional well cluster data (with monitoring intervals at different depths) reveals that during recharge or irrigation events, the vertical gradient is practically zero (or perhaps a very small downward gradient) suggesting that the shallow aquifer is well connected, as was previously observed by Lukasiewicz and Smith (1996). The opposite is true during dry periods with significant evaporation or during periods of extensive irrigation pumping. During these periods, the gradient is upward with the head difference measured at about $0.07 \mathrm{~m}$.

\subsection{Analysis of Site Specific Field Data}

The well data show that around the water farm the shallow wells respond directly to stage changes in the farm itself (e.g. CAU-2S, $4 S, 5 S$ ). Wells located adjacent to the $\mathrm{C}-44$ canal (e.g. CAU-7M, 7D) reflect the irrigation canal stages indicating a direct hydraulic connection of the SAS to the canal. Wells located in between the water farm and the $\mathrm{C}-44$ canal show effects from both the farm itself and the C-44 cCanal (e.g. CAU-6M, 6D). The surface water staff gauges reflect the stages in the water farm reservoir and irrigation pumping in the onsite distribution canals. For example, surface gauges SG-2 and SG-3 do not correlate with either the water farm or the C-44 canal but they do correlate with onsite irrigation pumping. UNF performed a correlation analysis between each onsite observation well and the stage inside the water farm reservoir. Table 2 shows the results indicating the correlation coefficient for each. A value close to 1.0 represents almost perfect correlation. A negative value indicates an opposite correlation. 
Table 2 Correlation between onsite instrument readings and water farm stage.

\begin{tabular}{cc}
\hline Instrument ID & Correlation Coefficient $(r)$ \\
\hline CAU-2S & 0.93 \\
CAU-3S & -0.26 \\
CAU-4S & 0.9 \\
CAU-5S & 0.99 \\
CAU-5M & 0.99 \\
CAU-5D & 0.98 \\
CAU-6M & 0.94 \\
CAU-6D & 0.93 \\
CAU-7M & 0.63 \\
CAU-7D & 0.69 \\
SG-2 & -0.39 \\
SG-3 & -0.36 \\
SG-5 & 0.88 \\
\hline
\end{tabular}

In reviewing the results of the correlation analysis, it is clear that the onsite irrigation canals can affect both surface gauges (e.g. SG-2 and SG-3) as well as nearby shallow wells (e.g. CAU-3S). Well CAU-4S also appears to be partially affected by nearby irrigation canals as its correlation coefficient is lower, at 0.90 , than those of other shallow wells. UNF interprets these results as showing that the onsite irrigation canals can act as groundwater sources to the SAS in some cases and localized groundwater sinks in other periods depending upon irrigation pumping. The onsite observation data also clearly indicate that downward recharge is occurring at the water farm and it appears that a majority of this recharge is moving downward in the SAS and then laterally away from the water farm in all directions. However, most of this water will eventually flow back to the C-44 canal and discharge as enhanced baseflow. The water level data at the water farm also indicate that the SAS is well connected vertically as well as horizontally. Water levels recorded at CAU-5S and $5 \mathrm{M}$ are practically identical with a slight downward gradient recorded.

\subsection{Model Construction and Results}

Following the methodology of the St. Johns River Water Management District (SJRWMD 2012), the NSE values for the Excel model are divided into intervals which explain the model performance rating. The intervals are as follows: $0.75<$ NSE $<1$ is a very good performance rating; $0.65<$ NSE $<0.75$ is a good performance rating; $0.50<$ NSE $<0.65$ is a satisfactory performance rating; and NSE $<0.50$ is an unsatisfactory performance rating. Table 3 shows the three goodness-of-fit statistics for the Excel-Solver water budget model.

Table 3 Goodness-of-fit model statistics for Excel water budget model.

\begin{tabular}{cc}
\hline Goodness-of-Fit Parameter & Calibration Result \\
\hline$r$ & 1 \\
$r^{2}$ & 0.99 \\
NSE & 0.99 \\
\hline
\end{tabular}

Figure 5 shows the final model predicted stage versus the actual observed stage at the water farm. Water level elevations in the water farm were estimated in cases where the water level fell below the invert elevation of the farm. This happened on two occasions as noted in Figure 5. It is clear from this figure and the values reported in Table 3 that the model is extremely accurate. The NSE value is indicative of very good performance.

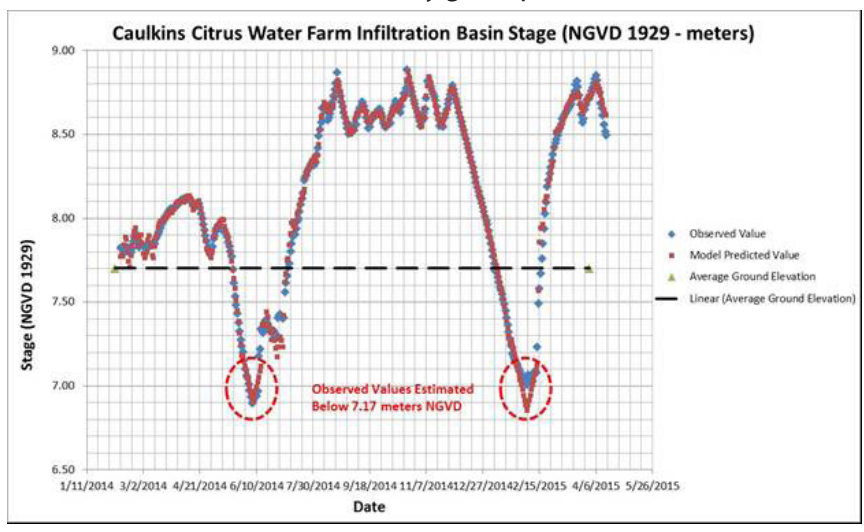

Figure 5 Calibration results of the Excel water budget model.

The preliminary MODFLOW model developed to support this study had limited objectives and was designed to support the Excel water budget model. Further detailed information regarding the MODFLOW model can be reviewed in UNF (2015). As the MODFLOW model is based upon groundwater flow physics, it was also used to ensure that recharge rates estimated by the Excel model were feasible given the area's hydrogeologic conditions. In everyday terms, the MODFLOW model constrained the realm of possible recharge rates such that the Excel model was certain to be more realistic.

Overall, the MODFLOW model results agreed with the Excel water budget model. The Excel water budget model estimated that the daily recharge rate into the SAS was $52253 \mathrm{~m}^{3} / \mathrm{d}$ (on November 17th) while the MODFLOW model estimated the recharge value to be $45485 \mathrm{~m}^{3} / \mathrm{d}$. These estimates are within $13 \%$ of each other. Similarly, for the MODFLOW validation period (November 20th) the Excel model estimated a daily recharge rate into the SAS of $52223 \mathrm{~m}^{3} / \mathrm{d}$ while the MODFLOW model estimated the recharge value to be $53790 \mathrm{~m}^{3} / \mathrm{d}$, within $\sim 3 \%$ of each other. Besides the good agreement between simulated and observed groundwater levels, the MODFLOW model was able to reproduce the estimated recharge rate derived in the Excel water budget model. The research team believes this provides a sound check on the results for each model tool.

\subsection{Data Synthesis and Overall Assessment}

With all of the necessary data assembled and simulation models developed, UNF was able to develop an overall assessment of the water farm performance. For this paper, the overall water budget (including evaporation versus percolation) and overall the cost effectiveness of the project are discussed. 
The calibrated Excel water budget model was utilized to assess performance of the water budget metric. The water budget model calculated the following total inflows and outflows from 2014-02-01 to 2015-04-15:

- Pump station inflow $=22524578 \mathrm{~m}^{3}$ (18 261 acrefeet);

- Precipitation inflow $=2227665 \mathrm{~m}^{3}$ (1 806 acre-feet);

- ET outflow = $2832070 \mathrm{~m}^{3}$ (2 296 acre-feet);

- Recharge or percolation outflow $=20379557 \mathrm{~m}^{3}$ (16 522 acre-feet); and

- Remaining water in storage $=1540616 \mathrm{~m}^{3}$ (1 249 acre-feet).

The minimum, maximum, mean, and median daily inflows and outflows are shown in Table 4.

Table 4 Daily inflow and outflow descriptive statistics.

\begin{tabular}{lcccc}
\hline \multicolumn{1}{c}{ Flow Component } & Mean & Median & Max & Min \\
\hline Pump station inflow $\left(\mathrm{m}^{3} / \mathrm{d}\right)$ & 51782 & 39299 & 157170 & 0.00 \\
Precipitation inflow $\left(\mathrm{m}^{3} / \mathrm{y}\right)$ & 5119 & 0.00 & 129713 & 0.00 \\
ET outflow $\left(\mathrm{m}^{3} / \mathrm{d}\right)$ & 6513 & 6858 & 8252 & 1123 \\
Recharge outflow $\left(\mathrm{m}^{3} / \mathrm{d}\right)$ & 46848 & 40125 & 132353 & 0.00 \\
\hline
\end{tabular}

Based on these data, it is evident that the water farm outflow is dominated by recharge to the SAS which is $\sim 6$ to 7 times greater than the ET outflow. An independent estimate of the mean daily recharge rate prepared by the SFWMD was determined to be about $41938 \mathrm{~m}^{3} / \mathrm{d}$ using data from 2014-02-10 to 2015-01-31 (SFWMD 2015). The SFWMD estimate is between the median and mean rates determined in this study. Therefore, for this performance measure the water farm performance was excellent. It should be noted that the original performance storage goal for the water farm pilot project was to store $8362994 \mathrm{~m}^{3} / \mathrm{y}$ while the actual site operations recorded more than twice that total over 12 months.

Overall, the water farm appears to be very cost effective when compared to proposed water storage alternatives nearby. The original cost of the adjacent C-44 reservoir component of the Everglades restoration was estimated at $\$ 112562000$. This cost was updated during development of the Indian River Lagoon (IRL) South Project Implementation Study (USACE 2004). This cost was estimated to be \$244 738375 (2003 dollars) and included a central reservoir of 3315 acres (1342 ha) and two STAs for a total of 6000 acres ( $2428 \mathrm{ha}$ ). It has been estimated that these features would store about $74625540 \mathrm{~m}^{3}$ (60 500 acre-feet) stormwater per year (USACE 2004) or possibly more in some years. Operation and maintenance (O\&M) costs were only estimated for the entire IRL project at $\$ 6144700$ (2003 dollars) so it has been assumed for this study that $25 \%$ of the O\&M cost is applied to the C-44 reservoir and STAs.

For this report the C-44 costs were inflated to 2015 costs using a Bureau of Labor Statistics inflation calculator (http://data. bls.gov/cgi-bin/cpicalc.pl) and then compared to the water farm pilot project on a per unit basis. Table 5 shows the comparison. Assuming a $40 \mathrm{y}$ life for both projects and an investment interest rate of 5\%, UNF calculated an equivalent annual cost for comparison purposes. In order to be over-conservative, UNF also assumed that the C-44 project could store up to $123348000 \mathrm{~m}^{3} / \mathrm{y}$ (100 000 acre-feet/y) water after further operational optimization (more than the reported estimates discussed above). It was further assumed that overall recharge efficiency of the water farm pilot project may decrease over time such that it can only store and process up to $12334800 \mathrm{~m}^{3} / \mathrm{y}$ (10 000 acre-feet/y) water.

Table 5 Comparison of storage costs.

\begin{tabular}{lcc}
\hline \multicolumn{1}{c}{ Cost Component } & C-44 and STA Cost $(\$)$ & Pilot Project Cost $(\$)$ \\
\hline Initial Construction & 313265120 & 1212000 \\
Operation \& Maintenance & 1966304 & 300000 \\
Unit Cost \$ per cubic meter & 0.164 & 0.03 \\
\hline
\end{tabular}

It is clear from this analysis that the water farm pilot project is extremely cost effective when compared with the planned C-44 reservoir and STA project. UNF conservatively estimates that the unit storage cost for the water farm pilot project is at least 5 times less than the $\mathrm{C}-44$ project.

\section{Conclusions}

A pilot artificial recharge water farm project was assessed over a period of $\sim 14$ months from 2014 to 2015 . The water farm project was successful in recharging the SAS with $\sim 82 \%$ water pumped from the C-44 canal. Evaporation loss was moderate and accounted for $\sim 11 \%$ of the water pumped into the impoundment with the remainder sitting in temporary storage in the water farm itself. Overall the project has been shown to be extremely cost effective, being less expensive than other comparable alternatives in the study area. Artificial recharge, or water farming, can provide many water resources benefits to the inhabitants of South Florida and elsewhere. Based upon the good performance of the pilot project, the State of Florida is cooperating with the owner to expand the site to more than 500 ha. Future studies need to confirm the water farm's effectiveness in treating inflow nutrient loads so that environmental restoration projects may also benefit from this innovative water management solution.

\section{References}

Abe, J. M. 1986. Economic Analysis of Artificial Recharge and Recovery of Water in Butler Valley, Arizona. Tucson, AZ: University of Arizona. Master's Thesis.

Abtew, W., J. Obeysekera and N. Iricanin. 2010. Pan Evaporation and Potential Evapotranspiration Trends in South Florida. West Palm Beach, FL: South Florida Water Management District. SFWMD Technical Paper 107

Asano, T. 1985. Artificial Recharge of Groundwater. Toronto: Butterworth Publications.

ASCE (American Society of Civil Engineers). 2001. Standard Guidelines for Artificial Recharge. New York: American Society of Civil Engineers. EWRI/ASCE 34-01. 
Bouwer, H. 1978. Groundwater Hydrology. New York: McGraw-Hill.

Bouwer, H., R. Pyne, J. Brown, D. St Germain, T. Morris, C. Brown, P. Dillon and M. Rycus. 2008. Design, Operation, and Maintenance for Sustainable Underground Storage Facilities. Denver, CO: AWWA Research Foundation.

Bouwer, H., R. G. D. Pyne and J. Goodrich. 1990. “Recharging Groundwater." Civil Engineering; New York 60 (6): 63-6.

Bouwer H., R. C. Rice, J. C. Lance and R G. Gilbert. 1980. “Rapid-Infiltration Research at Flushing Meadows Project, Arizona." Journal of the Water Pollution Control Federation 52:2457-70.

Brown, C. 2005. Planning Decision Framework for Brackish Water Aquifer, Storage and Recovery (ASR) Projects. Gainesville, FL: University of Florida. PhD Dissertation.

Brown, C. J., J. Vearil, P. Linton, T. Hendren and G. Whittle. 2014. "A Multi-Criteria Assessment of the C-111 Hydrologic Restoration Project-A Case Study." Water Resources Management 29 (9): 2453-69. https://doi.org/10.1007/s11269-014-0614-2

Brown, C. and students. 2015. Final Summary Report: An Independent Technical Assessment of Martin County, Florida Water Farming Pilot Project, State of Florida, USA. Jacksonville, FL: University of North Florida.

https://assets.documentcloud.org/documents/2519439/ university-of-north-florida-school-of.pdf

CDM (Camp Dresser \& McKee). 2004. Preliminary Geotechnical Engineering Evaluation for the C-44 Water Management Project. West Palm Beach, FL: Aquacalma.

Cederstrom, D. J. 1947. "Artificial Recharge of a Brackish Water Well." Virginia Chamber of Commerce, Richmond, VA 14 (12): 31, 71-3.

Desmond, G. 2007. High Accuracy Elevation Data Collection Project. Washington, DC: U.S. Geological Survey. Fact Sheet FS-16296

Driscoll, F. G. 1986. Groundwater and Wells, 2nd ed. St. Paul, MN: Johnson Filtration Systems Inc.

Frontline Systems. 2010. Solver. Incline Village, NV: Frontline Systems, Inc.

http://www.solver.com

Hamadeh, A. F. 2014. Soil Aquifer Treatment (SAT) and Constructed Wetlands (CW) Applications for Nutrients and Organic Micropollutants (OMPs) Attenuation Using Primary and Secondary Wastewater Effluent. Thuwal, Kingdom of Saudi Arabia: King Abdullah University of Science and Technology. Dissertation.

Harpaz, Y. and J. Bear. 1964. "Investigation on Mixing of Waters in Underground Storage Operations." In International Association of Scientific Hydrology, Commission of Subterranean Waters, Publication 64, 132-53. Wallingford, Oxfordshire: IAHS.

Hoy, N. D. 1964. Generalized Water-Table Contours in Southern Florida, Map Series No. 7, May, 1964. Tallahassee, FL: Florida Board of Conservation, Division of Geology.
Idelovitch, E., N. Icekson-Tal, O. Avrahamand and M. Michail. 2003. "The Long-Term Performance of Soil Aquifer Treatment (SAT) for Effluent Reuse." Water Science and Technology: Water Supply 3 (4): 239-46.

Lukasiewicz, J. and K. A. Smith. 1996. Hydrogeologic Data and Information Collected from the Surficial and Floridan Aquifer Systems Underlying the East Coast Planning Area. West Palm Beach, FL: Department of Water Resources Evaluation South Florida Water Management District. WRE \#337 Technical Publication 96-02.

Mao, L. M., M. J. Bergman and C. Tai. 2002. “Evapotranspiration Measurement and Estimation of Three Wetland Environments in the Upper St. Johns River Basin, Florida." Journal of the American Water Resources Association 5 (38): 1271-85.

McDonald, M. G. and A. W. Harbaugh. 1988. A Modular Three-Dimensional Finite-Difference Ground-Water Flow Model: Techniques of Water-Resources Investigations 06-A1. Denver, CO: U.S. Geological Survey. https://pubs.er.usgs.gov/publication/twri06A1

MilCor Group, Inc. 2013. Plan and Details, Caulkins Water Farm Pilot Project, Sheet 1 of 1. Hobe Sound, FL: The MilCor Group.

Miller, A. 1978. Water-Resources Setting, Martin County, Florida. Tallahassee, FL: U.S. Geological Survey. Water-Resources Investigation 77-68.

Miller, A. 1997. "Hydrogeology of Florida." In Geology of Florida, edited by A. F. Randazzo and D. S. Jones, 69-88. Gainesville, FL: University Press of Florida.

Nagarajappa, D. P., K. Manjunatha and N. T. Manjunath. 2010. "Effects of Soil Types on Performance of Soil Aquifer Treatment (SAT) System." In Proceedings, Indian Geotechnical Conference, 2010, GEOtrendz, 425-8. https://gndec.ac.in/ igs/ldh/conf/2010/articles/105.pdf

Nash J. E. and J. V. Sutcliffe. 1970. “River Flow Forecasting Through Conceptual Models Part I-A Discussion of Principles." Journal of Hydrology 10 (3): 282-90. https://doi.org/10.1016/0022-1694(70)90255-6

Nema, P., C. S. P. Ojha, A. Kumar and P. Khanna. 2001. “Techno-Economic Evaluation of Soil-Aquifer Treatment Using Primary Effluent at Ahmedabad, India." Water Resources 35 (9): 2179-90.

NRC (National Research Council). 1994. Ground Water Recharge Using Waters of Impaired Quality. Washington, DC: The National Academies Press.

Rabbani, G. and D. Munch. 2000. Technical Feasibility of Artificial Recharge of Reclaimed Wastewater and its Hydrologic Impacts on the Regional Groundwater System. Palatka, FL: St. Johns River Water Management District. Technical Publication SJ2000-2.

Schmidt, C. M., A. T. Fisher, A. Racz, C. Wheat, M. Los Huertos and B. Lockwood. 2011. “Rapid Nutrient Load Reduction During Infiltration of Managed Aquifer Recharge in an Agricultural Groundwater Basin: Pajaro Valley, California." Hydrological 
Processes 26 (15): 2235-47. https://doi.org/10.1002/hyp.8320

Schmidt, W. 1997. "Geomorphology and Physiography of Florida." In Geology of Florida, edited by A. F. Randazzo and D. S. Jones, 1-12. Gainesville, FL: University Press of Florida.

SFWMD (South Florida Water Management District). 1984. Aquifer Test Data for Martin County, Florida. In the DBHYDRO database, West Palm Beach, FL: South Florida Water Management District.

SFWMD (South Florida Water Management District). 2013. News Release: SFWMD Water Farming Pilot Project to Benefit St. Lucie Estuary. West Palm Beach, FL: South Florida Water Management District.

SFWMD (South Florida Water Management District). 2015. Seepage Investigation of the Caulkins Water Farm Pilot ProjectFirst Annual Report. West Palm Beach, FL: South Florida Water Management District. Technical Publication WS-37.

State of Florida (Department of Natural Resources, Division of Resource Management and Bureau of Geology). 1986. Hydrogeological Units of Florida: Compiled by Ad Hoc Committee on Florida Hydrostratigraphic Unit Definition. Tallahassee, FL: Southeastern Geological Society-Florida Geological Survey. Special Publication No. 28.

SJRWMD (St. Johns River Water Management District). 2012. St. Johns River Water Supply Impact Study. Palatka, FL: St. Johns River Water Management District. Publication No. SJ2012-1.

Suzuki, T., T. Katsuno and G. Yamaura. 1992. "Land Application of Wastewater Using Three Types of Trenches Set in Lysimeter and its Mass Balance of Nitrogen." Water Resources 26 (11): 1433-44. https://doi.org/10.1016/0043-1354(92)90062-9

State Climate Office of North Carolina. 2014. Data from 2002 to 2009. Raleigh, NC: NC State University. http://www.nc-climate.ncsu.edu/opencharts_month.php?station $=$ KVRB\&unit=inches
Tucker, W. A. and M. Diblin. 2007. Phase I Report-Wekiva River Basin Nitrate Sourcing Study. Newberry, FL: MACTEC. Prepared for the Florida Department of Environmental Protection and the St. Johns River Water Management District.

UNF (University of North Florida). 2015. An Independent Technical Assessment of Martin County, Florida Water Farming Pilot Project. Jacksonville, FL: UNF School of Engineering.

USACE (U.S. Army Corps of Engineers). 2000. Hydrologic Modeling System HEC-HMS. Davis, CA: USACE Institute for Water Resources Hydrologic Engineering Center.

USACE (U.S. Army Corps of Engineers). 2004. Final Integrated Project Implementation Report and Environmental Impact Statement, Central and Southern Florida Project, Indian River Lagoon - South, March 2004, 475 p. plus appendices.

USACE and SFWMD (U.S. Army Corps of Engineers and South Florida Water Management District). 1999. Central and Southern Florida Project Comprehensive Review Study: Final Integrated Feasibility Report and Programmatic Environmental Impact Statement. Jacksonville, FL: USACE and SFWMD

Van Cuyk, S., R. Siegrist, A. Logan, S. Masson, E. Fischer and L. Figueroa. 2001. “Hydraulic and Purification Behaviors and Their Interactions During Wastewater Treatment in Soil Infiltration Systems." Water Resources 35 (4): 953-64.

Vecchioli, J. 1976. Preliminary Evaluation of the Feasibility of Artificial Recharge in Northern Qatar. Reston, VA: U.S. Geological Survey. Open-File Report 76-540.

Wang, W. C., K. W. Chau, C. T. Cheng and L. Qiu. 2009. "A Comparison of Performance of Several Artificial Intelligence Methods for Forecasting Monthly Discharge Time Series." Journal of Hydrology 374 (3): 294-306.

Wilson, L. G. 1979. Artificial Recharge: A Review from the Plan of Study for a Demonstration Recharge Project in the Salt River Valley. Los Angeles, CA: U.S. Army Corps of Engineers. 